\title{
High Temperature Sliding Wear of NiAl-based Coatings Reinforced by Borides
}

\author{
Oleksandr UMANSKYI ${ }^{1}$, Olena POLIARUS ${ }^{1}$, Maksym UKRAINETS ${ }^{1}$ *, \\ Maxim ANTONOV ${ }^{2}$, Irina HUSSAINOVA ${ }^{2}$ \\ ${ }^{1}$ Frantsevich Institute for Problems of Material Science of NASU, Krzhyzhanovsky str., 3, 03680 Kyiv-142, Ukraine \\ ${ }^{2}$ Tallinn University of Technology, Ehitajate tee 5, 19086 Tallinn, Estonia \\ cross $^{\text {ref }}$ http://dx.doi.org/10.5755/j01.ms.22.1.8093
}

Received 12 September 2014; accepted 14 May 2015

\begin{abstract}
The development of composite materials (CM) in the systems "metal-refractory compound" is one of the up-to-date trends in design of novel materials aimed at operating under the conditions of significant loads at high temperature. To design such material, $\mathrm{NiAl}$, which is widely used for deposition of protective coatings on parts of gas-turbine engines, was selected for a matrix. To strengthen a NiAl under the conditions of intense wear and a broad temperature range (up to $1000{ }^{\circ} \mathrm{C}$ ), it is reasonable to add refractory inclusions. Introduction of refractory borides into matrix leads to a marked increase in metal wear resistance. In order to research the behavior of the designed composites at high temperatures and to study the influence of oxides on the friction processes, the authors carried out high temperature oxidation of CM of the above systems at $1000{ }^{\circ} \mathrm{C}$ for $90 \mathrm{~min}$. It was determined that all of the composites were oxidized selectively and that the thickness of oxide layers formed on the boride inclusions is 3-7 times that on the oxides formed on the NiAl matrix. The mechanism of wear of gas-thermal coatings of the $\mathrm{NiAl}-\mathrm{MeB}_{2}$ systems was studied for conditions of high temperature tribotests using the «pin-on-disc» technique. The obtained results indicate that introduction of $\mathrm{TiB}_{2}, \mathrm{CrB}_{2}$ and $\mathrm{ZrB} 2$ leads to their more intense oxidation during high temperature tribotests as compared to the matrix. The oxides formed on refractory borides act as solid lubricants, which promote a decrease in wear of the contact friction pairs. For more detailed investigation of the effect of tribo-oxidation products on the friction processes, tribotests were conducted for prior oxidized (at $900{ }^{\circ} \mathrm{C}$ ) coatings $\mathrm{NiAl}-15$ wt. $\% \mathrm{CrB}_{2}\left(\mathrm{TiB}_{2}, \mathrm{ZrB}_{2}\right)$.
\end{abstract}

Keywords: diboride, metallide, composite material, coating, high temperature oxidation, tribosynthesis, solid lubricant, wear resistance.

\section{INTRODUCTION}

Workability of parts and units in aircraft engines depends on their capability to endure high loads and corrosion and heat action of high temperature gas flows. It is therefore necessary to pay particular attention to capability of a constructional material to resist wear and corrosion, that is, to provide it with required wear, heat and corrosion resistances. The new generation of turboprop and gas-turbine engines has challenged still harder and higher operational requirements. The effective power of aircraft engines essentially depends on the density of the rolling turbine parts.

Adhesive wear is one of the most dangerous wear mechanisms, which can be obtained during friction. The adherence significantly increases at high temperature. One of the ways for reducing of adherence is usage of brittle intermetallic compounds [1].

Metallides on the basis of aluminum and nickel are among the promising materials that meet the above requirements. In particular, the $\mathrm{Ni}-\mathrm{Al}$ system is characterized by combination of high hardness with low density along with high corrosion resistance. The NiAl metallides are widely used in aerospace industry for protective coatings on turbine engine blades [2-6]. However, the use of unalloyed metallides in frictional units

\footnotetext{
* Corresponding author. Tel.: +380-44-4243131; fax: +380-44-4242131.

E-mail address: maximukrainets22@gmail.com (M. Ukrainets)
}

is limited because of their plasticity at high temperatures $[1,7,8,23,24]$.

To increase wear resistance of friction pairs in turbine engine parts, up-to-date some materials based on the $\mathrm{Ni}-\mathrm{Al}$ and $\mathrm{Fe}(\mathrm{Ni})-\mathrm{Cr}-\mathrm{Al}-\mathrm{Y}$ systems added with strengthening refractory oxides $\mathrm{HfO}_{2}$ and $\mathrm{ZrO}_{2}$ have been developed [5, 6, 8-17]. However, using oxides as functional fillers does not provide required oxide-matrix adhesion through the absence of wetting in these systems, which may cause their chipping and, as a result, increase in wear of friction couple. Taking the above into account, the authors made decision to develop materials on the basis of metallide/refractory boride systems. A lot of research work has been done on fabrication "NiAl/refractory boride"based composite materials and coatings [2-4, 18-24], but only several studies have been done on the tribological behavior of composite materials of $\mathrm{NiAl}-\mathrm{MeB}_{2}$ systems under high temperature sliding wear [2-4].

The present work is devoted to investigation of properties of both composite materials $(\mathrm{CM})$ on the basis of the NiAl-Ti $(\mathrm{Cr}, \mathrm{Zr}) \mathrm{B}_{2}$ systems and coatings from them. The selection of these borides as strengthening phases was based on their high hardness as well as high heat and wear resistances. Also, at high temperature on the surface of boride additives the composite oxide films, based on $\mathrm{Ni}, \mathrm{Al}$, $\mathrm{Cr}$, Ti or $\mathrm{Zr}$ can be formed [20]. These films can work as solid lubricant, that's why they can decrease the wear of the 
coatings due to removing the adhesion between the friction surfaces $[1,8,15,16]$.

\section{EXPERIMENTAL PROCEDURE}

Commercial powders of refractory materials such as $\mathrm{CrB}_{2}, \mathrm{ZrB}_{2}, \mathrm{TiB}_{2}$ and $\mathrm{NiAl}$ were used as initial components for composite powders intended for manufacture of coatings. The composite powders $\mathrm{NiAl}-15 \mathrm{wt} . \% \mathrm{TiB}_{2}$, $\mathrm{NiAl}-15$ wt. $\% \mathrm{ZrB}_{2}$ and $\mathrm{NiAl}-15$ wt. $\% \mathrm{CrB}_{2}$ were prepared via conglomeration of the initial components on organic binder followed by sieving them up to $70-100 \mu \mathrm{m}$ fraction. Coatings were sprayed using air plasma spraying (APS) technique. The spraying conditions are listed in Table 1. The thickness of coatings was $\sim 500 \mu \mathrm{m}$.

Table 1. APS-spraying conditions

\begin{tabular}{|c|c|}
\hline \multicolumn{2}{|c|}{ Plasma gases flow rate, $l /$ min } \\
\hline Argon $(\mathrm{Ar})$ & 50 \\
\hline Hydrogen $\left(\mathrm{N}_{2}\right)$ & $12 \ldots 15$ \\
\hline \multicolumn{2}{|c|}{ Power parameters } \\
\hline Current, $A$ & $350 \ldots 360$ \\
\hline Voltage, $V$ & 65 \\
\hline \multicolumn{2}{|c|}{ Spraying conditions } \\
\hline Distance, $\mathrm{mm}$ & 120 \\
\hline Deposition rate, $\mathrm{kg} / \mathrm{hr}$ & 2 \\
\hline
\end{tabular}

Keeping in mind that these materials are designed for coatings working under the conditions of high temperatures and loads, first of all the authors prepared composite powders for deposition of coatings.

To establish the effect of $\mathrm{Ti}, \mathrm{Cr}$ and $\mathrm{Zr}$ diborides addition on the intensity and mechanism of wear of plasma coatings on the basis of $\mathrm{NiAl}$, the obtained coatings were subjected to tribotests. Coatings for tribotests were sprayed onto the ends of cylinder samples $(\mathrm{h}=10 \mathrm{~mm}, \varnothing=10 \mathrm{~mm})$. Sprayed coatings were grinded using the grinding machine before the tribotesting. Thereby average surface roughness was in the range $0.4-0.6 \mu \mathrm{m}$ rms. The tests were conducted using a friction machine equipped with a high temperature $\left(500^{\circ} \mathrm{C}\right)$ module according to the scheme «pin-on-disc». The counterbody was plasma $\mathrm{NiAl}$ coating. The parameters of testing were as follows: load $\mathrm{N}=8 \mathrm{MPa}$, number of revolutions $1.4 \mathrm{~m} / \mathrm{s}$, and friction path $1000 \mathrm{~m}$. The intensity of wear was calculated as the wear loss divided by the friction path. The wear loss was calculated from the difference of mass of the samples before and after the sliding of $1000 \mathrm{~m}$.

To reveal the wear mechanism in the coatings, process of high temperature oxidation of compact samples was studied.

Compact $\mathrm{CM}$, such as $\mathrm{NiAl}-15 \mathrm{wt} . \% \mathrm{TiB}_{2}$, $\mathrm{NiAl}-15$ wt. $\% \mathrm{ZrB}_{2}$ and $\mathrm{NiAl}-15$ wt. $\% \mathrm{CrB}_{2}$, were fabricated via sintering of green bodies from initial powder mixtures at $1800{ }^{\circ} \mathrm{C}$ in a helium atmosphere.

The designed composite materials of the NiAl-MeB ${ }_{2}$ systems are aimed at operating in high temperature friction assemblies in the form of both compact materials and coatings. Processes running during operation of them at high temperatures are of interest. The established regularities for oxidation of CM under study make it possible to elucidate the mechanisms of wear in materials operating at high temperatures. This will allow one to control processes of tribosynthesis of intermediate antifrictional oxide phases formed under friction and thus to achieve high tribological characteristics of $\mathrm{CM}$ and coatings [1]. High temperature oxidation of composites was conducted in air in a laboratory electric furnace at $1000{ }^{\circ} \mathrm{C}$ for $90 \mathrm{~min}$. In order to quantitatively estimate the thickness of the oxide layers formed after high temperature oxidation, the Auger analysis was used.

Upon testing, the microstructure, chemical composition of compact CM, coatings from them and friction surfaces of the coatings were examined using JEOL JSM-840 (EDXanalysis) and JEOL JAMP-9500F (Auger-analysis) microanalyzers respectively.

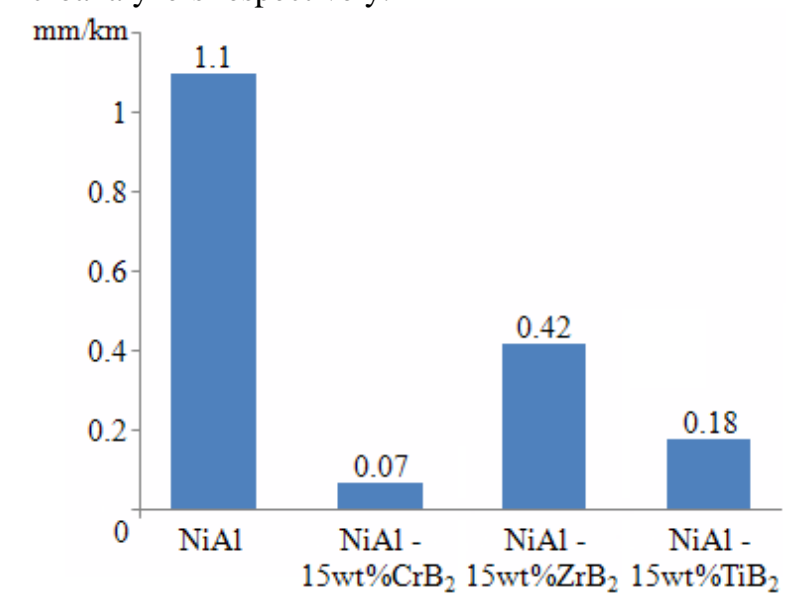

Fig. 1. Intensity of wear for plasma coatings

\section{RESULTS AND DISCUSSION}

In order to determine wettability and compatibility of initial components, physicochemical interactions were investigated in the systems «metallide-boride» including determination of contact angles of wetting and examination of the interaction zone. Herein no active chemical interaction was observed, and contact angles were within $0^{\circ}-20^{\circ}$. These results allowed for using $\mathrm{Ti}, \mathrm{Cr}$ and $\mathrm{Zr}$ borides as strengthening phases for the metallide NiAl.

The carried-out tribotesting investigations (Fig. 1) revealed that the greatest wear is characteristic for the initial plasma coating $\mathrm{NiAl}$. It is worth noticing that addition of each boride markedly increased wear resistance of the metallide but the composite coating $\mathrm{NiAl}-15 \mathrm{wt} . \% \mathrm{CrB}_{2}$ proved to be the most effective of all. Obviously, the reason for the increase in wear resistance of strengthened composite coatings as compared with that of the initial metallide is based on the fact that under friction boride particles undertake predominant part of the load because they wear slightly thanks to higher hardness $[1,7,8,20,23,24]$.

The mechanism of wear was studied using the SEManalysis of friction surfaces (Fig. 2). Herein the following peculiarities were revealed: the friction surface of $\mathrm{NiAl}$ coating contained defect areas in the form of pickup of the friction products, namely oxides (Fig. 2 a). The friction track was in the form of 50-200 $\mu \mathrm{m}$ wide grooves, which is evidence to seizure of the sample surface with the counterbody material. The EDX-analysis indicated that the friction surface structure was composed of oxide layers on 
the basis of $\mathrm{Ni}$ and $\mathrm{Al}$ (supposedly, spinel $\mathrm{NiAl}_{2} \mathrm{O}_{4}$ ) and $\mathrm{Al}_{2} \mathrm{O}_{3}$. Besides, there was fixed a phase corresponding to the metallide NiAl. Evidently, preliminary heating during tribotests $\left(500{ }^{\circ} \mathrm{C}\right)$ caused local oxidation of contact surfaces in the form of oxide films on the basis of $\mathrm{Ni}$ and $\mathrm{Al}$. Spinel films were spongy and easy to separate and remove from the friction zone, which increased wear. Furthermore, in the course of high temperature tribotests the surface of $\mathrm{NiAl}$ coating was partly covered with an oxide $\mathrm{Al}_{2} \mathrm{O}_{3}$ film as well, which destroyed through high plastic deformation and partly moved out of the friction zone. This may lead to seizure of contact friction surfaces, which resulted in increasing coating wear. These results correlate with known tribological theories and research results $[1,7,8]$.

The structure of the friction surface of the $\mathrm{NiAl}-15$ wt. $\% \mathrm{CrB}_{2}$ coating was uniform with no marked defects and areas of seizure and tear-out of material. As seen in Fig. 2 b, by the microanalysis, the structure of friction surface of this coating is similar to that of the initial coating and is composed of two phases, namely the dominant NiAlbased phase and $\mathrm{CrB}_{2}$-based phase.

The friction surface of the coating $\mathrm{NiAl}-15$ wt. $\% \mathrm{ZrB}_{2}$ is characterized by the presence of areas with adhered counter-body material and nonuniform distribution of slip lines over the friction surface. By the microanalysis data, this coating is characterized by the presence of a continuous oxide layer which contains $\mathrm{Ni}, \mathrm{Al}$ and $\mathrm{Zr}$ oxides on the friction surface (Fig. $2 \mathrm{c}$ ). With further growth such layers separate and remove from the friction zone, which causes an increase in wear.

The friction surface of the $\mathrm{NiAl}-15$ wt. $\% \mathrm{TiB}_{2}$ coating is characterized by occasional areas of seizure (Fig. 2 d). Therefore a conclusion may be drawn that under friction in the composite plasma $\mathrm{NiAl}-15 \mathrm{wt} . \% \mathrm{TiB}_{2}$ and $\mathrm{NiAl}-15$ wt. $\% \mathrm{ZrB}_{2}$ coatings an oxidation-adhesion mechanism of wear is predominantly realized, which consists in oxidation of contact friction pair followed by removing oxides formed. The microstructure findings are consistent with the results for the intensity of coating wear.

To study the effect of the oxides formed on friction surfaces on the mechanisms of wear, compact $\mathrm{CM} \mathrm{NiAl}-15$ wt. $\% \mathrm{CrB}_{2}, \quad \mathrm{NiAl}-15$ wt. $\% \mathrm{ZrB}_{2}$ and $\mathrm{NiAl}-15$ wt.\% $\mathrm{TiB}_{2}$ were oxidized in air at $1000{ }^{\circ} \mathrm{C}$ for 90 min (Fig. 3). Herein it was established that all of the composites were oxidized selectively and the intensity of oxide formation on refractory inclusions was several times higher than that on the metallide matrix.

All of the composites oxidized at high temperature were characterized by the formation of dense and continuous oxide layers on the metallide matrix, whose composition, by the microanalysis data, corresponded to aluminum and boron oxides (Fig. $3 \mathrm{a}-\mathrm{c}$, spot 1). In contrary, oxide formations on the surfaces of refractory conclusions, namely grains of chromium diboride (Fig. 3 a, spot 2), titanium diboride (Fig. 3 a, spot 3 ) and zirconium diboride (Fig. 3 a, spot 4) were loose and their thickness was much greater than that of oxide layers on the metallide matrix (Fig. $3 \mathrm{a}-\mathrm{c}$ ).

The conducted experiments concerning high temperature oxidation of the developed compact CM made it possible to establish the mechanism of wear in the tribosystems (NiAl-Cr(Ti, $\left.\mathrm{Zr}) \mathrm{B}_{2}\right)$ - NiAl under friction at high temperature $\left(500^{\circ} \mathrm{C}\right)$. It may be presented as follows: addition of diborides leads to decrease in the resistance to plastic deformation of the metallide and thus blocks destruction of oxide layers formed on composite coating under friction [7-8, 23-24].

Additionally, the oxides formed on diboride grains in the course of tribosynthesis play the part of a solid lubricant, which at the initial stages of friction prevents the coatings $\mathrm{NiAl}-\mathrm{MeB}_{2}$ and $\mathrm{NiAl}$ from seizure, and then the oxides formed on the metallide matrix work $[1,8]$.
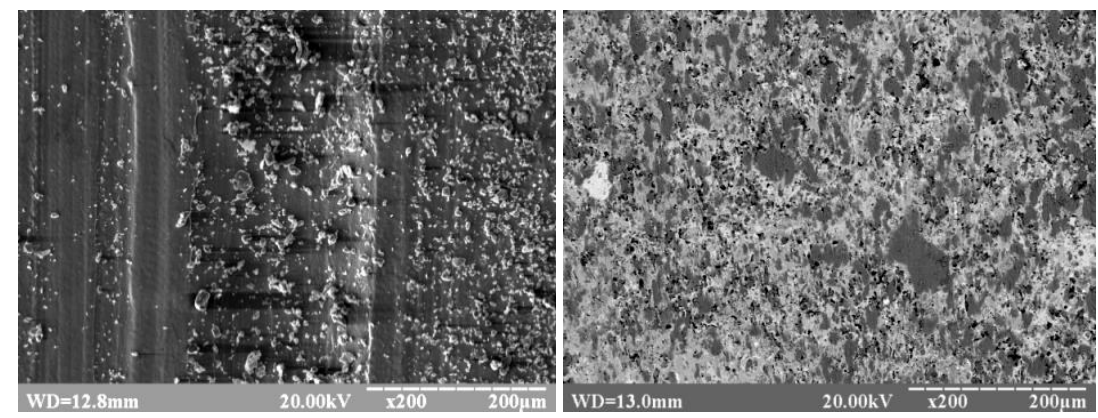

a

$\mathrm{b}$

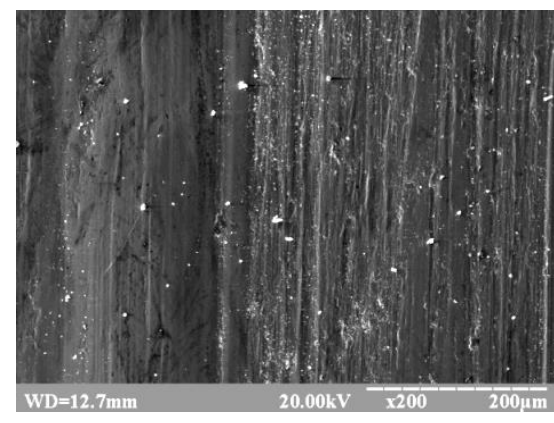

$\mathrm{c}$

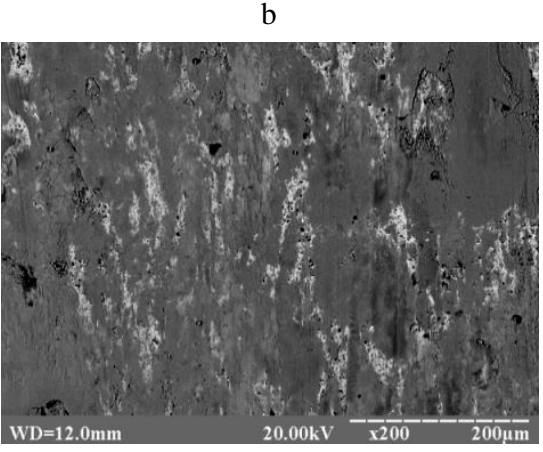

d

Fig. 2. Microstructure of coating friction surfaces after tribotests at $500{ }^{\circ} \mathrm{C}$ with a counterbody coating from $\mathrm{NiAl}$ for: a- $\mathrm{NiAl}$; b-NiAl- 15 wt. $\% \mathrm{CrB}_{2} ; \mathrm{c}-\mathrm{NiAl}-15$ wt. $\% \mathrm{ZrB}_{2} ; \mathrm{d}-\mathrm{NiAl}-15$ wt.\% $\mathrm{TiB}_{2}$ 


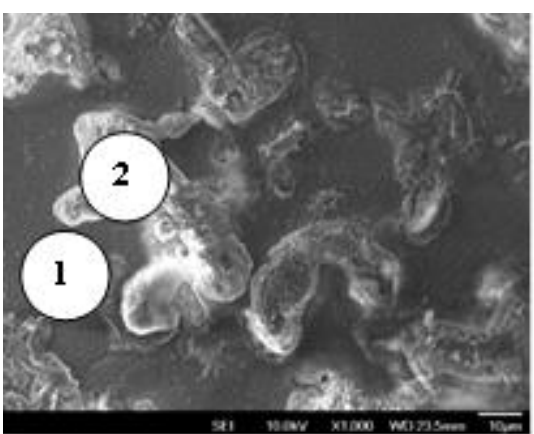

a

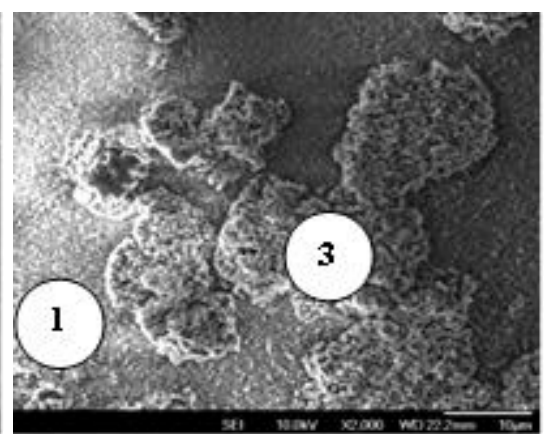

b

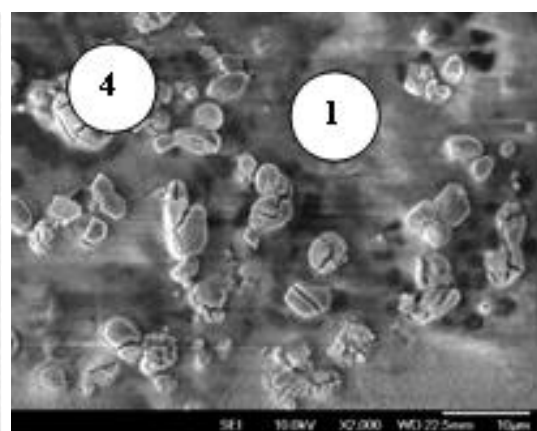

Fig. 3. Microstructure of $\mathrm{CM}$ after oxidation in air at $1000{ }^{\circ} \mathrm{C}$ for $90 \mathrm{~min}$ : $\mathrm{a}-\mathrm{NiAl}-15 \mathrm{wt} . \% \mathrm{CrB}_{2} ; \mathrm{b}-\mathrm{NiAl}-15 \mathrm{wt} . \% \mathrm{TiB}$; $\mathrm{c}-\mathrm{NiAl}-15$ wt. $\% \mathrm{ZrB}_{2} ; 1$-aluminum and boron oxides; 2-grains of chromium diboride; 3 -grains of titanium diboride; 4 - grains of zirconium diboride

The investigation of oxidized surfaces of developed composites has shown that oxidation of the $\mathrm{CM}$ $\mathrm{NiAl}-15$ wt.\% $\mathrm{CrB}_{2}$ results in forming loose oxide layers on the boride grain surfaces.According to the microanalysis data, the composition of the layers corresponds to complex oxides on the basis of $\mathrm{Cr}, \mathrm{B}$ and $\mathrm{Al}$, namely $\mathrm{Cr}_{2} \mathrm{O}_{3}+\mathrm{Al}_{2} \mathrm{O}_{3}+\mathrm{B}_{2} \mathrm{O}_{3}$ (Fig. 3 a). The thickness of this oxide layer is thrice that of the oxide on the metallide matrix.

During oxidation of CM NiAl-15wt\% $\mathrm{TiB}_{2}$ oxide phases are formed on titanium diboride grains in the form of volumetric conglomerations of $1-2 \mu \mathrm{m}$ scales. The sizes of the conglomerations fall in the region 5-15 $\mu \mathrm{m}$, which agrees with the sizes of titanium diboride grains in the initial composite (Fig. 3 b). According to the Auger-analysis data, such formations corresponds to aluminum-alloyed titanium oxide $\mathrm{Ti}(\mathrm{Al}) \mathrm{O}$ and $\mathrm{TiO}_{2}[20]$. Their thickness is 5 times that of the oxide layer on the $\mathrm{NiAl}$ matrix.

$\mathrm{CM} \mathrm{NiAl-15}$ wt. \% $\mathrm{ZrB}_{2}$ is characterized by formation of porous cracked oxide layers on inclusions of zirconium diboride (Fig. $3 \mathrm{c}$ ). The reason for cracking may be transition of $\mathrm{ZrO}_{2}$ under heating (to $1000{ }^{\circ} \mathrm{C}$ ) from the stable low-temperature monoclinic modification into the metastable tetragonal one, which is accompanied by reduction in the volume of zirconium oxide by $\sim 7 \%$.

The microanalysis data showed that on zirconium diboride grains the $\mathrm{ZrO}_{2}$ oxides are formed, the thickness of which is greater than that of the oxide layers by 7 times.

To sum up, a selective oxidation may positively affect the operation of the developed CM at high temperatures and loads as the formed oxides may play the role of a solid lubricant and thus prevent contact friction pairs from seizure, which finally leads to increase in wear resistance. The obtained results correlate with known tribological theories and the previous research results $[1,15]$.

\section{CONCLUSIONS}

The effect of addition of $\mathrm{Ti}, \mathrm{Cr}$ and $\mathrm{Zr}$ diborides on the wear resistance of developed composite NiAl-based coatings was studied on the basis of high temperature tribotests using a NiAl coating as a counterbody. The wear resistance of the coatings was established to be much greater than that of the initial metallide coatings. On the one hand, the introduction of the above additives into metallide was demonstrated to result in increasing rigidity and strength of coating, which partly prevent $\mathrm{Ni}$ and $\mathrm{Al}$ based oxides from destruction thanks to reduction in plastic deformation of the metallide matrix at high temperatures. On the other hand, $\mathrm{TiB}_{2}, \mathrm{CrB}_{2}$ and $\mathrm{ZrB}_{2}$ inclusions oxidize more intensely compared to the NiAl matrix and the formed oxides can serve as a solid lubricant, which leads to increase in the material wear resistance.

\section{Acknowledgements}

This work was supported by Estonian Ministry of Education and Research and by Estonian Science Foundation (IUT 19-29, grant 8850, Maksim Antonov).

\section{REFERENCES}

1. Bhushan, B., Kennedy, F., Szeri, A. Macrotribology in Modern Tribology Handbook (Section I) / Edited by Bharat Bhushan. CRC Press LLC, Boca Raton, Florida, 2000. http://dx.doi.org/10.1201/9780849377877

2. Umanskyi, O., Poliarus, O., Ukrainets, M., Dovgal, A., Kapitanchuk, L., Subbotin, V. The Structure and Properties Investigations of Composite Materials and Coatings Based on NiAl-TiB 2 Systems [in Russian] Aerospace Technique and Technology 10 (107) 2013: pp. 20-24.

3. Umanskyi, O., Poliarus, O., Ukrainets, M., Kostenko, O., Terentyev, O. Influence of $\mathrm{CrB}_{2}$ Additives into $\mathrm{NiAl}$ Intermetallics on Tribological Properties of Thermal Spray Coatings at High Temperature Friction Conference MET2013: Materials, Environment, Technology, Latvia, Riga 2013: pp. $37-43$.

4. Umanskyi, O., Poliarus, O., Ukrainets, $M$., Martsenyuk, I. Effect of $\mathrm{ZrB}_{2}, \mathrm{CrB}_{2}$ and $\mathrm{TiB}_{2}$ Additives on the Tribological Characteristics of NiAl-Based Gas-thermal Coatings Key Engineering Materials 604 2014: pp. $20-23$. http://dx.doi.org/10.4028/www.scientific.net/KEM.604.20

5. Bolshakov, V., Kharchenko, V., Zhuravel, V., Zahorodnyi, A., Liubushkin, V., Zamrkovoi, V., Miloserdov, A. Investigation of Heat Protective Running-in Coatings for Turboprop Engine Retainers [in Russian] Construction, Materials Science, Mechanical Engineering: Sat scientific Works 45 (1) 2008: pp. 87-91.

6. Migunov, V., Farafonov, D., Dehovets, M., Stupina, T. Sealing Materials for Gas Flow Regions of Turbine Engines [in Russian] Aviation Materials and Technologies S 2012: pp. $94-97$.

7. Darolia, R., Lahrman, D.F., Field, R.D. Overview of NiAl for High Temperature Structural Application Ordered 
Intermetallics-Physical Metallurgy and Mechanical Behavior 3 1992: pp.679-698.

http://dx.doi.org/10.1007/978-94-011-2534-5_43

8. Guo, J., Wang, Z., Sheng, L., Zhou, L., Yuan, C., Chen, Z., Song L. Wear Properties of NiAl Based Materials Progress in Natural Science: Materials International 22 (5) 2012: pp. $414-425$.

9. He, L., Tan, Y., Wang, X., Tan, H., Zhou, C. Tribological Properties of WC and $\mathrm{CeO}_{2}$ Particles Reinforced In-situ Synthesized NiAl Matrix Composite Coatings at Elevated Temperature Surface \& Coatings Technology 244 2014: pp. $123-130$.

10. Hussainova, I., Antonov, M., Voltsihhin, N. Assessment of Zirconia Doped Hardmetals as Tribomaterials Wear 271 2011: pp. 1909-1915.

11. Movahedi, B. Fracture Toughness and Wear Behavior of NiAl-based Nanocomposite HVOF Coatings Surface \& Coatings Technology 235 2013: pp. 212-219.

12. Sheng, L. Y., Yang, F., Xi, T.F., Guo, J.T. Investigation on Microstructure and Wear Behavior of the NiAl-TiC- $\mathrm{Al}_{2} \mathrm{O}_{3}$ Composite Fabricated by Self-propagation High-temperature Synthesis with Extrusion Journal of Alloys and Compounds 554 2013: pp. $182-188$.

13. Sheng, L.Y., Yang, F., Guo, J.T., Xi, T.F., Ye, H.Q. Investigation on $\mathrm{NiAl}-\mathrm{TiC}-\mathrm{Al}_{2} \mathrm{O}_{3}$ Composite Prepared by Self-propagation High Temperature Synthesis with Hot Extrusion Composites: Part B 45 2013: pp. 785-791. http://dx.doi.org/10.1016/j.compositesb.2012.05.038

14. Sheng, L.Y., Guo, J.T., Xi, T.F., Zhang, B.C., Ye, H.Q. $\mathrm{ZrO}_{2}$ Strengthened $\mathrm{NiAl} / \mathrm{Cr}(\mathrm{Mo}, \mathrm{Hf})$ Composite Fabricated by Powder Metallurgy Progress in Natural Science: Materials International 22 (3) 2012: pp. 231-236.

15. Shi, X., Zhai, W., Wang, M., Xu, Z., Yao, J., Song, S., Wang, Y. Tribological Behaviors of NiAl Based SelfLubricating Composites Containing Different Solid Lubricants at Elevated Temperatures Wear 310 2014: pp. 1-11.

16. Zhua, S., Bi, Q., Niua, M., Yanga, J., Liua, W. Tribological Behavior of NiAl Matrix Composites with Addition of Oxides at High Temperatures Wear 274-275 2012: pp. 423-434.
17. Zikin, A., Antonov, M., Hussainova, I., Katona, L., Gavrilovic, A., Winkelmann, H. High Temperature Wear of Cermet Particle Reinforced NiCrBSi Hardfacings Tribology International 68 2013: pp. 45-55. http://dx.doi.org/10.1016/j.triboint.2012.08.013

18. Cui, H., Ma, L., Cao, L., Teng, F., Cui, N. Effect of NiAl Content on Phases and Microstructures of $\mathrm{TiC}-\mathrm{TiB}_{2}-\mathrm{NiAl}$ Composites Fabricated by Reaction Synthesis Transactions of Nonferrous Metals Society of China 24 2014: pp. 346-353.

19. Erdem Camurlu, H., Maglia, F. Self-propagating Hightemperature Synthesis of $\mathrm{ZrB}_{2}$ or $\mathrm{TiB}_{2}$ Reinforced $\mathrm{Ni}-\mathrm{Al}$ Composite Powder Journal of Alloys and Compounds 478 2009: pp. $721-725$. http://dx.doi.org/10.1016/j.jallcom.2008.11.139

20. Hou, S., Liu, Z., Liu, D., Ma, Y. Oxidation Behavior of $\mathrm{NiAl}_{-} \mathrm{TiB}_{2}$ Coatings Prepared by Electro-thermal Explosion Ultrahigh Speed Spraying Physics Procedia 32 2012: pp. $71-77$.

21. Hou, S., Liu, Z., Liu, D. The Study of NiAl-TiB 2 Coatings Prepared by Electro-Thermal Explosion Ultrahigh Speed Spraying Technology Surface \& Coatings Technology 205 2011: pp. $4562-4568$.

22. Shokati, A. A., Parvin, N., Shokati, M. Combustion Synthesis of NiAl Matrix Composite Powder Reinforced by $\mathrm{TiB}_{2}$ and TiN Particulates from Ni-Al-Ti-BN Reaction System Journal of Alloys and Compounds 585 2014: pp. $637-643$. http://dx.doi.org/10.1016/j.jallcom.2013.09.020

23. Whittenberger, J.D., Kumar, S., Mannan, S.K., Viswanadham, R.K. Slow Plastic Deformation of Extruded $\mathrm{NiAl}_{-10 \mathrm{TiB}_{2}}$ Particulate Composites at 1200 and $1300 \mathrm{~K}$ Journal of Materials Science Letters 9 (3) 1990: pp. 326-328. http://dx.doi.org/10.1007/BF00725839

24. Whittenberger, J.D., Viswanadham, R.K., Mannan, S.K., Sprissler, B. Elevated Temperature Slow Plastic Deformation of NiAl-TiB 2 Particulate Composites at 1200 and 1300K Journal of Materials Science 25 (1) 1990: pp. 35-44. http://dx.doi.org/10.1007/BF00544181 